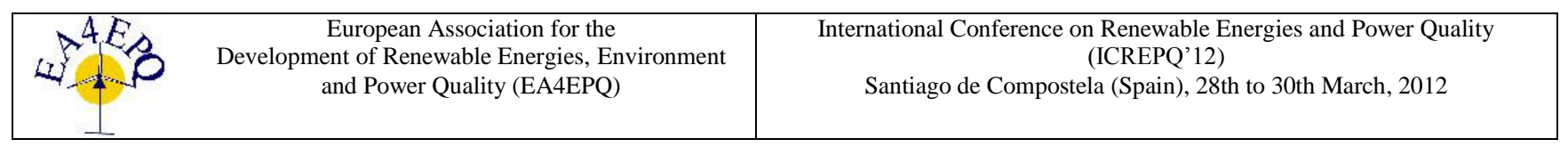

\title{
Poultry litter: great potential for electrical energy generation in Brazil
}

\author{
Baldin. V ${ }^{1}$, Frozza. J. $F^{2}$ Lafay. J. $S^{3}$ \\ PGPEE - Post Graduate Program in Electrical Engineering of UTFPR - Federal Technological University of Paraná- \\ Campus of Pato Branco, Brazil \\ ${ }^{1}$ Baldin. V, vitorbaldin@ $@$ hotmail.com, ${ }^{2}$ Frozza. J. F, janquiel@gmail.com, ${ }^{3}$ Lafay. J. S, jean.utfpr@gmail.com
}

\begin{abstract}
Due to the rapid industrialization and population growth there is a higher energy demand. As a result of this factor the greenhouse effect has been aggravating the weather around the globe. Many countries are seeking for sources of renewable and clean energy in order to reduce the air pollution. The biomass energy is an alternative that may interest everyone, since it is a renewable source and there are several technologies for its processing. This study aims to quantify the generation of poultry litter in the production of broiler chickens in the country, to identify the technologies for the available energy conversion, to quantify the potential for electrical energy generation and indicate through technical analysis the most feasible technology to explore the energy potential. In Brazil the biomass derived from the poultry litter represents $1 \%$ of all the available biomass, compared to the straw and sugar cane bagasse, regarding the biomass used in the electrical energy generation this percentage increases to $7 \%$. Using the process which is more efficient (gasification) with the poultry litter produced in the country in $2010\left(8.23 \times 10^{9} \mathrm{~kg}\right)$, it is estimated a production of $503.77 \mathrm{MW}$. This energy may be injected into the network to meet the demand at times of increased consumption.
\end{abstract}

\section{Key words}

Poultry litter, biomass, power generation, Brazil, energy sustainability.

\section{Introduction}

Due to the fast industrialization and population growth at a rapid pace, there is a demand for more and more energy. It is known that the sources of fossil fuels, widely used, are limited and they are running out. The burning of fossil fuels releases large amounts of pollutants into the atmosphere. The release of these pollutants in the form of gases in large quantities is deposited in the atmosphere and causing the global warming.

The greenhouse effect is caused by the concentration of gases in the atmosphere, which has the capacity to hold the infrared radiation emitted by the earth increasing the surface temperature of the planet. According to [1], the greenhouse gases are carbon dioxide $\left(\mathrm{CO}_{2}\right)$, methane $\left(\mathrm{CH}_{4}\right)$, nitrous oxide $\left(\mathrm{N}_{2} \mathrm{O}\right)$ sulfur hexafluoride $\left(\mathrm{SF}_{6}\right)$ and perfluorocarbons compounds $\left(\mathrm{CF}_{4}\right)$, the perfluoretano $\left(\mathrm{C}_{2} \mathrm{~F}_{6}\right)$ and hydrofluorocarbons ( $\mathrm{HFCs}$ ).

In order to reduce the emission of gases that cause the greenhouse effect, it has been searching other sources of energy, renewable energy (solar, wind, biomass energy, etc.). Some of these energy sources are found throughout of the planet's surface, but due to the technological constraints and its use that is economically unviable many of these sources are not being exploited significantly.
The countries with temperate climates have the longest daily time of clear solar radiation and better conditions for the development of biomass. According to [2], India is one of the countries with great potential for power generation through biomass, since it has a climate that promotes the development of the culture of certain species. The contribution of the renewable energy is among $4 \%$ to $18 \%$ of the total power generation in the country.

[3] presents Croatia as another country with a great potential for electrical energy generation through biomass, because in this country the predominant industrial activity is the lumber industry. This activity is responsible for $44 \%$ of the country's economy and generates large amounts of waste. However, there are just few projects in development for that purpose. Even the companies that use wood as raw material do not use the waste to generate electrical energy. They only use the waste to produce heating energy to their basic needs.

\section{A. Objectives of the issue}

This study is part of the dissertation in PGPEE (Post Graduate Program in Electrical Engineering) of UTFPR (Federal Technological University of Paraná) and it aims to quantify the production of poultry litter concerning the broiler chickens production in the country, to identify the technologies for the available energy conversion, to estimate the potential for energy generation and indicate through economic technical analysis the most feasible technology to explore the energy potential of this waste in the country. The analysis of energy conversion processes will make possible to indicate the most feasible technology for the utilization of such waste on the national scenery.

\section{Theoretical Reference}

\section{A. Biomass Energy}

Biomass is a renewable energy source derived from several natural and human wasting. These residues are derived from organic matters produced on the planet, which are derived from land, aquatic and animal matters. The energy obtained from biomass does not produce unwanted effects on the environment, because the cycle on this conversion maintains the balance in the release of gases such as $\mathrm{CO}_{2}$, it means, the gases that are released in the use of biomass for power generation, are absorbed in plant growth [2]. 
And also many of these waste used as biomass end up not being addressed to inappropriate places such as rivers, lakes, and forests.

Biomass is found abundantly in agricultural sectors, in crop cultivation, animal management and the urban sectors, with industrial and human wastes.

\section{B. Extraction processes of biomass energy}

Biomass energy can be turned out into electrical energy through technologies like: direct combustion, coincineration, gasification, pyrolysis, anaerobic digestion and fermentation.

In the direct combustion, according to [2], the burning of biomass is caused in order to obtain thermal energy which is used to heat liquids that can be used for several purposes, including the generation of steam to generate electricity.

In the process of gasification, biomass is exposed into temperatures about $350{ }^{\circ} \mathrm{C}$ with oxygen, transforming the biomass into gaseous element. This gas is a mixture of carbon monoxide, carbon dioxide, nitrogen, hydrogen and methane. These gaseous elements may be used as fuel and may be burned in several processes for electricity generation, [2].

Another process for reusing the biomass is pyrolysis. This process consists in heating the biomass at temperatures from 500 to $900{ }^{\circ} \mathrm{C}$, changing it into solid, liquid or gaseous matter. In this process, the objective is to remove the volatile matter that produces a gas composed of hydrogen and carbon monoxide, leaving the resultant matter of the process with double of density. It is also possible to obtain liquid materials known as oil of pyrolysis and oil of phenol. The fuels derived from pyrolysis, gas and pyrolysis oil can be burned to generate thermal energy and after that into electricity because of its oxidizing characteristics.

The digestion of biomass using micro-organisms is known as anaerobic digestion. This process depends on microorganisms which have the objective to break down the biomass. In the absence of oxygen, about 60 to $80 \%$ of the carbons contained in organic matter are converted into carbon dioxide, hydrogen, nitrogen and mostly (approximately 55\%) into methane gas [2].

For this process to occur with greater efficiency, it is recommended that the acidity ( $\mathrm{pH}$ - potential Hydrogen) of the substrates is maintained at values between 6 and 7 with a temperature in the fermentation tank from $25^{\circ} \mathrm{C}$ to $37^{\circ} \mathrm{C}$ [3].

However [4] reported that anaerobic digestion tanks operate more efficiently with wet agricultural residues tested in the laboratory with a temperature in the tanks of digestion at $38{ }^{\circ} \mathrm{C}$ to $45^{\circ} \mathrm{C}$. This temperature of $38{ }^{\circ} \mathrm{C}$ to $45{ }^{\circ} \mathrm{C}$ can be provided by heat exchangers which have as source of thermal energy the solar radiation, or the residual heat from combustion engines used to burn this biogas to generate electricity. The biomass used in this process can be derived from plant and animal residues, but this process can vary in temperature, acidity and time depending on the type of matter used as biomass.

\section{Electricity production from biomass}

All the processes used for the conversion of biomass such as: direct combustion, gasification, pyrolysis, anaerobic digestion and fermentation obtained compounds in the form of liquid, solid or gaseous which in the sequence are used to generate electricity. In the combustion is generated thermal and mechanical energy to be used in the generation of electricity through the power plants.

\section{Composition of biogas}

According to [5], the provided biogas from animal biomass (manure) is a mixture of approximately $50 \%$ to $70 \%$ of methane, $30 \%$ to $35 \%$ of carbon dioxide and $5 \%$ of hydrogen sulfide, nitrogen and oxygen can also be found in smaller quantities.

\section{E. Features in the combustion of biogas in internal combustion engines}

The predominant methane in the biogas mixture is highly flammable and when burned it is converted into carbon dioxide and water. Biogas has up to $35.9 \mathrm{MJ} / \mathrm{m}^{3}$ of energy while coal is between $24 \mathrm{MJ} / \mathrm{kg}$ and $37 \mathrm{MJ} / \mathrm{kg}$. This methane has a burning of $0.373 \mathrm{~m} / \mathrm{s}$. As referred to the biogas this burning is approximately $0.23 \mathrm{~m} / \mathrm{s}$. That is because the biogas is composed of other gases [5].

In relation to the methane of biogas, the energy released with $50 \%$ of methane is $17.95 \mathrm{MJ} / \mathrm{m}^{3}$ and for $70 \%$ of methane is $25.13 \mathrm{MJ} / \mathrm{m}^{3}$.

According to [5], the combustion of biogas in internal combustion engines occurs in a delayed-form in comparison with pure methane combustion, but this problem can be solved by increasing the compression ratio in the combustion chamber and with reinforcement of the mixture to increase the energy in the ignition.

\section{F. Characteristics of confinement modules (sheds)}

For the production of broilers is used some growing houses configurations to improve their performance. These houses are built according to economic factors and climate (regarding to the appropriate conditions of temperature and relative humidity, ventilation, radiation, etc.), and according to the standard of the growing houses used by the company which the broiler farmer will commercialize the birds.

Nowadays, due to the fact that Brazil is a tropical country and the Brazilian poultry industry is composed of a very large number of small and medium companies, there is a diversification in these facilities (houses). There are houses with full manual control of the environment and other ones fully air conditioned (Dark-House).

In Facilities where the air conditioning is controlled manually by the operators of the system, the efficiency of the production flock depends on the operator's performance and may negatively affect the performance of the birds. In these cases, lower densities are used due to the large labor force needed for the operation of the house [6].

\section{G. Poultry litter management}

The management of broiler flocks influences on bird performance. This management is the way how the chicken feed, the cooling and lighting of the broilers to the exit of the flocks will be conducted. 
The management of the broilers is defined taking into account the lineage, sex, climate of the region and by the company that is selling the birds. The companies that buy these broilers produce a product mix that follows patterns and for keeping this product mix the birds must have a different management system [7].

\section{H. Lineage of broilers}

Another factor but no less important to the poultry farming is the lineage of birds, because each lineage has its own characteristics (density of birds $/ \mathrm{m}^{2}$ and management programs) that must be observed to obtain the best performance from the broiler flock, and consequently in the poultry litter production [8].

Besides the lineage, according to [8], the sexing of birds also contributes to the performance from the flock, because the density in male broiler flock varies in comparison to the ones of females. According to [9] the male chickens have better performance in comparison to the females with the same density $/ \mathrm{m}^{2}$.

\section{Materials and Methods}

\section{A. The poultry industry in Brazil}

Brazil is one of the countries with the highest agricultural production in the world and the poultry farming is an activity that stands out. This poultry activity began in the $50 \mathrm{~s}$ and since then, there has been an accelerated development of the activity in the country.

According to reports [10], the Brazilian poultry industry has been growing at a rapid pace. The production of broilers in 2010 rose $12 \%$ in comparison to 2008 .

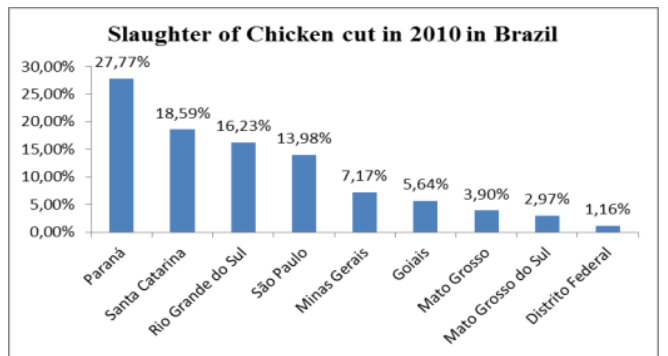

Figure 01: Exportation of Chicken Cut in Brazilian states

The poultry activity requires intensive utilization of technologies, resulting in large power consumption in the processes to provide the final product: the chicken meat. In report 2010/2011 presented by the [11], it is observed in Figure 01 that the state of Parana had the highest production of broiler chickens in 2010, 27.77\%. Santa Catarina is in the second place with $18.59 \%$, Rio Grande do Sul with $16.23 \%$ and São Paulo with $13.98 \%$ in production of broiler chickens. These four states in 2010 produced $76.57 \%$ of the total production of broiler chickens in Brazil.

In this report 2010/2011, it is also observed that the states with the highest production of broiler chickens are the greatest exporters of chicken meat, the exported amount reached 3,819.710 tons of meat. Concerning the total, the state of Santa Catarina exported 26.71\%, Paraná 26.19\%, Rio Grande do Sul $20.95 \%$ and São Paulo $6.99 \%$.

The meat production expected for 2021 is 16 million tons, while for 2011 is expected 12 million tons. This perspective of development is a result of a high consumption of chicken meat in Brazilian domestic market due to the growth rate of the country and also by the increase of exports.

In 2011 it has been expected a growth of 4\% in comparison to the year of 2010 . This growth is because the increase of domestic consumption and also due to the negotiation concerning the certification of plants for spreading out the Brazilian exports by the authorities [12].

\section{B. Estimated production of poultry litter in Brazil}

The poultry litter is composed of excrement and urine of birds, humidity and process substrates (wood shavings, sawdust, rice hulls, feed, etc.).

According to [8], with a density of 10.16 and 22 birds $/ \mathrm{m}^{2}$, it was obtained an average of $33.72 \%$ of moisture for the first flock. In the second production flock being put on the poultry litter of the first flock with densities of 10, 16 and 22 birds $/ \mathrm{m}^{2}$, it was obtained an average of $29.26 \%$ of moisture. These average values of moisture are contents using sawdust as a substrate pin pad.

It is known that the moisture of the poultry litter as well as its production, are also influenced by the type of absorbent material of waste, facilities, equipments, density and management adopted at the farm. It is very important then to consider such variables in the production of poultry litter since such factors may determine the highest or lowest potential for producing the poultry litter.

The absorbent material of waste is put on the chicken coop before placing the poultry chicks. The researchers [13], evaluating four types of bedding (wood shaver, rice hulls, coffee hulls and ground corn cob) on the performance of broilers, observed no significant variation in weight gain, feed intake and feed conversion. Thus, it is concluded that the researched absorbent materials provide to the birds a similar performance.

The population density to be adopted is determined by a number of factors like, area, where the farm is located, strain of birds, equipment availability, period of the year and duration of the cycle.

To [14], it is common to use the population density of up to $40 \mathrm{birds} / \mathrm{m}^{2}$ for the first 21 days, with subsequent housing transfer and reduction in density.

To determine the potential for generation of poultry litter waste is necessary to determine the coefficient of waste. This value is calculated by the total amount of dry waste generated by the birds in the periods of accommodation, divided by its weight as shown in the equation below.

$$
C_{R}=\frac{k g_{\text {gama }}}{P_{S}}
$$

Here it is observed: $C_{R}$ coefficient of waste, $\mathrm{kg}_{\text {cama }}$ amount of poultry litter and $\mathrm{P}_{\mathrm{s}}$ weight of live birds.

[8] used in his experiment $0.442 \mathrm{~kg}$ of dry sawdust for each bird housed with a density of 16 birds $/ \mathrm{m}^{2}$ in new poultry litter. At the end of 42 days of accommodation it was obtained a total average of $1.37 \mathrm{~kg}$ of dry poultry litter for each bird, and from this total, $0.930 \mathrm{~kg}$ of dry matter of debris have been added by the birds. 
[8] also concluded that for every kilogram of live chicken were produced an average of $0.590 \mathrm{~kg}$ of dry waste.

[1] used in his analysis an average density of 12.46 birds $/ \mathrm{m}^{2}$, considering $23 \%$ of moisture in fresh poultry litter. It was calculated an average value of $2.04 \mathrm{~kg} / \mathrm{dry}$ matter (poultry litter) per bird. For this conclusion [1] did not consider in his work the influence of spongy materials, installations of the chicken coops, bird management type and lineage.

Using as reference the values supported by [8], it can be calculated the production of poultry litter in the country involving the production of chicks housed or cutting production in pounds of live chicken.

\begin{tabular}{|c|c|c|c|c|c|}
\hline \multicolumn{6}{|c|}{ Chicks Crop Production (million head) } \\
\hline & 2007 & 2008 & 2009 & $\mathbf{2 0 1 0}$ & 2011 \\
\hline January & 420,5 & 460,7 & 417,7 & $\mathbf{4 7 2 , 9}$ & 499,35 \\
\hline February & 390,8 & 427,9 & 406,9 & $\mathbf{4 4 8 , 9}$ & 473,3 \\
\hline March & 423,4 & 441,1 & 425,6 & $\mathbf{5 1 0 , 4}$ & 526,84 \\
\hline April & 414,3 & 429 & 455,7 & $\mathbf{4 9 7 , 6}$ & 513,02 \\
\hline May & 433,5 & 455,5 & 461,8 & $\mathbf{5 0 1}$ & 536,04 \\
\hline June & 418,8 & 437 & 482,1 & $\mathbf{5 0 0 , 8}$ & 514,1 \\
\hline July & 434,6 & 476,1 & 500,3 & $\mathbf{5 1 2 , 4}$ & \\
\hline August & 444,8 & 454,3 & 482,7 & $\mathbf{5 1 4 , 8}$ & \\
\hline September & 424,4 & 485,3 & 467,9 & $\mathbf{4 9 6 , 9}$ & \\
\hline October & 463,4 & 496,1 & 503 & $\mathbf{5 1 3 , 1}$ & \\
\hline November & 431,5 & 431,7 & 462,6 & $\mathbf{5 1 1 , 5}$ & \\
\hline December & 451,8 & 443,8 & 494 & $\mathbf{5 1 7 , 8 2}$ & \\
\hline TOTAL & 5151,8 & 5438,5 & 5560,3 & $\mathbf{5 9 9 8 , 1 2}$ & 3062,65 \\
\hline
\end{tabular}

Figure 02: Table with production of broiler chicks in Brazil

In accordance with [12], the production of broiler chicks in 2010 was an amount of 5,998,127,000 heads, figure 02 .

Figure 02 presents details about broiler chick production for the years of 2007, 2008, 2009, 2010 and the beginning of 2011.

Using these data in combination with the results obtained by [8], it is concluded that the production of poultry litter in Brazil in 2010 is close to $8.23 \times 10^{9} \mathrm{~kg}$ of dry matter. The total of this $8.23 \times 10^{9} \mathrm{~kg}$ of dry matter, $2.65 \times 10^{9} \mathrm{~kg}$ are substrates (wood shavings, sawdust, rice hulls, feed, etc.) Used as an absorbent for the absorption of bird excrements and $5.58 \times 10^{9} \mathrm{~kg}$ are detritus added by the birds.

To get to this result of poultry litter it was used the figure 03 (table with the variables used in the calculations).

\begin{tabular}{|l|c|l|}
\hline \multicolumn{3}{|c|}{ Production of poultry litter on a dry basis } \\
\hline density of birds & 16 & birds/m \\
\hline Substratum & 0,442 & $\mathrm{~kg}$ bird of dry matter \\
\hline Debris & 0,93 & $\mathrm{~kg}$ bird of dry matter \\
\hline Broiler Chicks Production in 2 & 5998127000 & Chicks \\
\hline Substratum & $2,65 \mathrm{E}+09$ & $\mathrm{~kg} /$ year of dry matter \\
\hline Debris & $5,58 \mathrm{E}+09$ & $\mathrm{~kg} /$ year of dry matter \\
\hline Total & $\mathbf{8 , 2 3 \mathrm { E } + 0 9}$ & $\mathrm{kg} /$ year of dry matter \\
\hline
\end{tabular}

Figure 03: Production of poultry litter on a dry basis.

Where in this figure 03: The density of birds represents the number of birds per $\mathrm{m}^{2}$, substrate is the amount of poultry litter placed in the chicken coop before housing the birds and the detritus are the excrements deposited by birds.

In this chart it is estimated the total quantity in kilograms of substrate, also calculates the amount of detritus deposited by the birds to get the total of $8.23 \times 10^{9} \mathrm{~kg}$ of dry matter as shown in the chart above.

\section{Estimated production of biogas from the poultry litter using biodigesters}

In the process of anaerobic digestion, the organic matter present in wastewater is converted by the action of micro- organisms in approximately $78 \%$ in biogas (a mixture of methane $\left(\mathrm{CH}_{4}\right)$ and carbon dioxide $\left.\left(\mathrm{CO}_{2}\right)\right), 20 \%$ of organic material that remains in dissolution, and 1 to $2 \%$ of new micro-organisms [8].

The possibilities of biological conversion of the poultry litter into biogas have been demonstrated through several practical and scientific reports. This biological conversion of organic waste is the conversion from the action of bacteria causing the biomass oxidation. The bacteria use the chemical components such as carbon dioxide $\left(\mathrm{CO}_{2}\right)$, nitrate $\left(\mathrm{NO}_{3}\right)$ and sulfate $\left(\mathrm{SO}_{4}{ }^{2-}\right)$ to yield the final product of organic matter oxidation. This process consists of two stages. In the first stage act anaerobic and facultative bacteria which transform organic compounds of carbohydrates, lipids and proteins into volatile acids. In the second stage act strictly anaerobic bacteria that convert volatile acids into gases such as methane and carbon dioxide [15].

Also validates the potential to generate biogas for the poultry industry waste. This potential generation depends on factors as: type of food, season, type of poultry litter, density of bird housing, reuse of the poultry litter and other factors.

[8] used in his study three types of poultry litter (bed) in two production flocks, validating for the first flock an average production of $0.21 \mathrm{~m}^{3}$ of biogas per $\mathrm{kg}$ of total solids. For the second flock, it was validated 0.249 $\mathrm{m}^{3} / \mathrm{kg}$.

[1] also showed the production of $0.54 \mathrm{~m}^{3}$ of biogas per $\mathrm{kg}$ of dry matter (poultry litter). Comparing with the data validated by [1] with the data of [8], it was verified that there is a considerable difference in the results. For a production of $8.23 \times 10^{9} \mathrm{~kg}$ of poultry litter (secretion and substrate) is calculated using the data validated by [8], a production of approximately $20.49 \times 10^{8} \mathrm{~m}^{3}$ of biogas in the year 2010 in Brazil.

This biogas can be used in direct combustion through the burners to warm up places, or it can be used in generator set to provide electricity. The activation of the generators can be powered by internal combustion engines (Otto cycle engine), gas microturbine and gas turbine.

Each type of drive has a specific yield. In Otto cycle engines, the yield is approximately $15 \%$, in gas micro turbines this income is close to $27 \%$ and the gas turbine is approximately $33 \%$ [1].

\section{Estimated production of electricity from biogas}

Using the equations presented by [1], it is possible to calculate the power generation in $\mathrm{kW}$ for the three types of existing shareholders (Otto cycle engine, gas microturbine and gas turbine).

$$
P_{a}=P C I \times V_{b} \times \eta_{a}
$$

Where: $\mathrm{P}_{\mathrm{e}}$ expresses the electric power, PCI the lower calorific value of biogas $\left(22,600 \mathrm{~kJ} / \mathrm{m}^{3}\right)$ and $\eta_{\mathrm{a}}$ the yield of the equipment to drive the generator.

The amount of $20.49 \times 108 \mathrm{~m} 3$ of biogas have a potential for generating electricity by generator set powered by Otto cycle engine of about 220.27MW per year. At the touch of microturbine generator with gas this value increases to $396.49 \mathrm{MW}$ a year and it may reach 484.60 MW a year in the use of gas turbine. 
This production presented above is one of the existing ways to generate energy from poultry litter. The following topics are approached other ways to generate energy from the litter poultry.

\section{E. Estimated production of electricity from the gasification of poultry litter}

To [16], gasification is the conversion of any liquid or solid biomass into energetic gas through the partial oxidation of biomass at high temperatures. This gas can be used in gas-fired thermal plants to generate electricity through thermal generation plants with high power. It is a thermochemical conversion of biomass with the possibility of using the obtained gas.

The poultry litter is a polydisperse biomass. In this case it is necessary its compaction. This compression is done through the pelleting process. This process consists in passing the poultry litter in presses and form pellets. To [16], one of the most important factors that should be taken into consideration is the moisture biomass.

For the poultry litter is recommended a moisture proportion from 80 to $20 \%$. Humidity values above $20 \%$ make unfeasible the gasification process, because there is a high consumption of energy to remove the moisture.

According to [17], in the United States 35 million tons of manures per year are used as biomass in which represents $18 \%$ of raw materials derived from agriculture. For the extraction of biomass energy are used the processes of pyrolysis, anaerobic digestion, gasification and direct combustion.

In the experiment done [17] in wet gasification process, it was produced $54 \% \mathrm{CH}_{4}, 45 \% \mathrm{CO}_{2}$ and $1 \% \mathrm{H}_{2}$. These results were obtained for all the examined residues. At the end of the experiment the researchers show an article with an energy value of $13,832 \mathrm{~kJ} / \mathrm{kg}$ of the gas produced from dry matter using the gasification process with wet poultry litter.

Using the data validated by [17], in association with the production of poultry litter in Brazil in 2010 and also using an efficiency of approximately $22 \%$ presented by [16] in his dissertation for systems using the combustion engine otto cycle, it is estimated that the energy generated in the poultry litter through the process of Gasification is close to 503.77MW a year.

\section{F. Estimated production of electricity from the direct combustion of poultry litter}

The direct burning of biomass is the combustion and transformation of chemical energy into heat through of the reactions of the constituent elements with oxygen. This process occurs mainly in furnaces and boilers because the process is more efficient and simple to be conducted.

The United States is the country that invests more in technologies for using biomass to generate electricity. In the 70 decade it had a generation of $200 \mathrm{MW}$; this generation rose to $8.4 \mathrm{GW}$ in the 90 's and in 2010 was $18 \mathrm{GW}$. For 2030 it is intended to reach an output of approximately $100 \mathrm{GW}$ of electricity by burning agricultural residues and animal manure. Nowadays, the poultry industry produces 17 million tons of poultry litter per year [12].
To produce $18 \mathrm{GW}$ of energy in 2010 the United States has installed a plant in the U.S. state of Minnesota with a burning capacity of 500 tons of turkey litters per year.

In this process the steam generated by burning the turkey litter is used to move turbines capable of generating electric power of 55MW [12]. It is also verified through the figure 04 the main producer states of poultry litter in 2010. This figure 04 also shows that the state of Georgia is the largest producer of broiler followed by Arkansas and Alabama.

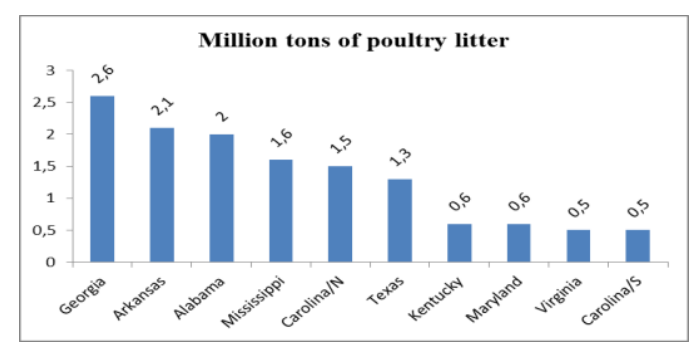

Figure 04: American States production of poultry manure in tons

As stated by [18], the calorific value of poultry litter can vary from $11,600 \mathrm{~kJ} / \mathrm{kg}$ to $16,100 \mathrm{~kJ} / \mathrm{kg}$. These values are essentially because the moisture of the poultry litter (bed). For purposes of quantifying energy it is going to be used the lower value.

As mentioned previously, the dry matter production in 2010 in Brazil was approximately $8.23 \times 10^{9} \mathrm{~kg}$. The energy value of this poultry litter amount is approximately $9.55 \times 10^{16} \mathrm{~J} /$ year or $3.03 \times 10^{9} \mathrm{~J} / \mathrm{s}$.

According to [18], the poultry litter can be burned in a boiler system and coupled generator (Rankine cycle). The efficiency of this system can range from 25 to $35 \%$. Taking advantage of the steam exhaust and using other processes the yield may increase to $85 \%$.

\section{Results}

In the paper presented, it was made a survey about the amount of poultry litter produced in Brazil in 2010. It was calculated a total of approximately 8.23 X $109 \mathrm{~kg}$ of dry matter (poultry litter) for the year of 2010 with a production of 5,998,127,000 head of poultry farming. It was also showed the possibilities of using this poultry litter to produce electricity through three distinct processes: gasification, direct combustion and through anaerobic digestion, in this study the process of gasification was the one with the greater efficiency.

The energy produced in the gasification reached the theoretical value of $503.77 \mathrm{MW} /$ year with the use of 8.23 $\mathrm{X} 10^{9} \mathrm{~kg}$ of dry matter, in the anaerobic digestion was estimated around 220MW/ year using a generator set powered by Otto cycle engine with an efficiency of $15 \%$. To drive the microturbine generator with the gas efficiency of $27 \%$, this value increases to $396.49 \mathrm{MW}$ year and it can reach $484.60 \mathrm{MW} /$ year in the use of gas turbine with an efficiency of $33 \%$.

The perspective verifies the total potential energy concerning the poultry litter from Brazil. A further study would consider the use of poultry litter for being used in distributed generation.

The distributed generation is evaluated when there is the need of transporting the poultry litter to large distances. 
It would be necessary another study to quantify the feasibility of using a distributed generation in comparison to a single generating unit, taking into consideration logistic factors for the biomass transportation (poultry litter).

Biomass for energy in general in Brazil is among the most likely renewable sources, because it has a wide availability of agricultural products which comprise about $90 \%$ of the cropland in Brazil, it is estimated that the supply of biomass residues as a source primary energy in 2005 reached 558 million tons per year on a dry basis [19], from this total of biomass the residues derived from broilers are not considered, only the vegetable residues.

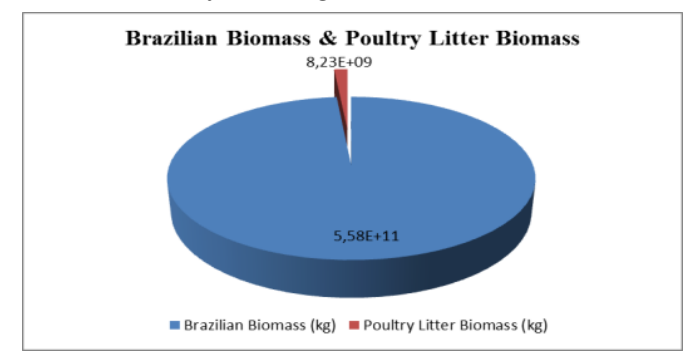

Figure 05: Biomass production in Brazil

In Figure 05 it is verified that the biomass derived from broilers represents $1 \%$ of the biomass produced in Brazil. Currently there are few types of residues that are used for generating electricity, only agro-industrial residues such as: bagasse (straw and bagasse), rice husk and wood.

In comparison to the bagasse and sugar cane straw, biomass that is used to generate electricity, the biomass, poultry litter may be contributing to $7 \%$, in the amount of biomass used for electricity generation, this information can be viewed in Figure 06.

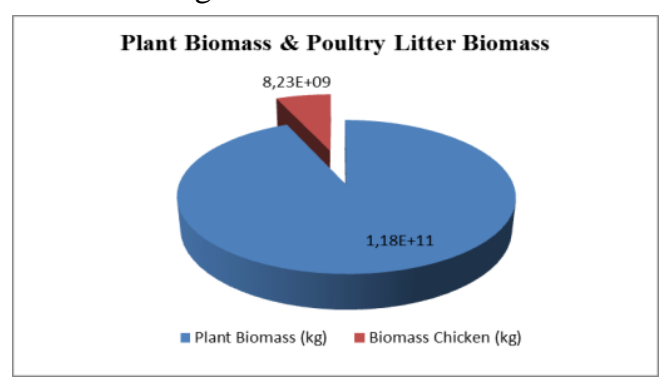

Figure 06: poultry litter versus sugar cane bagasse

\section{Final Considerations}

The energy potential of poultry litter is significant in the national context, in 2005, it represents $1 \%$ of all the biomass in Brazil and 7\% in comparison with the straw and sugarcane bagasse, biomass which has a great use in generating electricity. It was verified the amount of energy that sometimes is not being utilized correctly and it may be part of the national energy source, contributing with a significant portion. This energy can be injected at the times of higher energy demand in order to give relief to the other power plants.

\section{References}

[1] Ferrarez. A. H, Analysis of the Feasibility of Biogas Using as Energy Source in the Production Chain of broilers in the Zona da Mata of Minas Gerais, Dissertation, Federal University of Viçosa, Minas Gerais, Brazil 2009.
[2] Mrinalini. D, Biomass: A Sustainable Source of Energy, Assam Engineering Institute, India, IEEE 2009.

[3] Vukobratovic. M, Sljivac. D, Nikolovski. S, Energy Potencial and so Far Course of Action of Using Biomass and Biogas in Croatia, Faculty of Electrical Engineering in Osijek, Croácia, $20^{\circ}$ International Conference on Eletricity Distribution 2009.

[4] You. Z, You. S, Li. X, Hao. C, Biogas Power Plants Waste Heat Utilization Researches, School of Environment Science and Technology, Tianjin University, end College of Mechanical Engineering, Shijiazhuang Railway Institute, China, IEEE 2009

[5] Ling. S, Guowei. R, Zhaobo. H, Rukun. Z, Refitting Design of Miniature Biogas Generating System, Faculty of Engineering and Technology, China, IEEE 2011.

[6] Nascimento. L. A. B, Energy Analysis in poultry production: Economic Feasibility Study for a System of Electric Power Generation Wind-PV Connected to Network, Dissertation, Federal Technological University of Parana, Pato Branco, Brazil, 2011.

[7] Cobb, Manual Handling Broilers, Guapiaçu - Sao Paulo, Brazil 2009.

[8] Santos. T. M. B, Energy Balance and Adequacy of the use of digesters in Broiler Sheds, Thesis, UNESP, Jaboticabal, Brazil 2001.

[9] Albuquerque. R, Marchetti. L. K, Fagundes. A. C. A. F, Bittencourt. L. C, Neto. M. A. T e Lima. F. R, Effect of different population densities and sex on performance and Uniformity in Broilers, Vet Res Anim. Sci, v. 43, n.5, p.581-587, 2006.

[10] http://aveworld.com.br/relatorios/post/usda-brazil-poultryand-products-semi-annual-report-2011, acesso em 29/06/2011

[11] UBABEF-Brazilian Poultry Association, Annual Report 2010/2011, Brazil, 2011

[12] http://www.avisite.com.br/economia/estatistica.asp?acao= producaopintos, acesso em 10/10/2011.

[13] Araújo. J. S, Oliveira. V, e Braga. G. C, Performance of Broilers Reared in Different Types of Bed Capacity and Rate, Brazilian Animal Science, v.8, n.1, p.59-64, 2007.

[14] CONTE, A.J. Effects of stocking density in the initial phase of the transfer of housing with 21 days years oldand the type of bedding in the performance of broilers. 1997. 82 f. Dissertation (MSc in Animal Production) - Federal University of Lavras, Lavras, 1997.

[15] Silva. W. R, Kinetic Study of the Process of Anaerobic Digestion of Solid Waste Plant, PhD Thesis, University of Paraíba, Graduate Program in Chemistry, Joao Pessoa, Brazil 2009.

[16] Neitzke. G, Distributed Power Generation from the Pellets Gasification of poultry litter, master's thesis in mechanical sciences, University of Brasilia, Brazil 2010.

[17] Ro.K. S, Cantrell. K, Elliott. D, e Hunt. P. G, Catalytic Wet Gasification of Municipal and Animal Wastes, American Chemical Society, 2007.

[18] Sordi. A, Souza. S. N. M, Oliveira. F. H, Biomass produced from the poultry production in the western region of Paraná State: an energy source, Acta Sci Technol, Maringa, Brazil, v.27, n.2, p. 183-190, 2005.

[19] Ministry of Mines and Energy, National Energy Matrix in 2030, Brazil, 2007.

\section{Aknowledgement}

The authors acknowledge FINEP, CAPES, SETI, CNPq, and Fundação Araucária, for scholarships, funding and support to this work. 